\title{
Implementation of the Kedirgantaraan Coaching Program in Fostering a Sense of Nationalism in Students
}

\author{
Devi Lia Pebrianti ${ }^{1, *}$ Dasim Budimansyah ${ }^{2}$ \\ ${ }^{1,2}$ Universitas Pendidikan Indonesia, Bandung, Indonesia \\ ${ }^{*}$ Corresponding author.Email: deviliap23@upi.edu
}

\begin{abstract}
Nationalism in the younger generation has decreased due to the inclusion of various global views and the existence of framing that shows that the government is not being fair to citizens, causing distrust and diminishing the nationalism of the younger generation. This condition shows that there is a need for efforts in the educational aspect in the form of Kedirgantaraan guidance to foster a sense of nationalism in students. This study used a qualitative approach with a case study method, where the research was carried out at Angkasa Husein Sastranegara Senior High School of Bandung City, data collection techniques used interviews, observation and documentation, and data analysis used reduction, presentation and conclusion. The results showed that the Kedirgantaraan coaching program was carried out by developing students' knowledge of the geographic aspects of Indonesia which were rich in resources, teaching students the importance of a sense of belonging among citizens and territories of the Indonesian unity, and inviting students to carry out campaigns. which aims to invite people to care about the environment and citizens. The conclusion in this study is that the Kedirgantaraan coaching program is carried out in three aspects, namely cognitive, affective and psychomotor for students to foster a sense of nationalism.
\end{abstract}

Keywords: Kedirgantaraan, Nationalism, Learners.

\section{INTRODUCTION}

Education is a necessity for a human life. Education is a process of changing attitudes and behavior of a person or group through teaching and training efforts [1]. Through education and awareness of the importance of human education, it is expected that human beings have ethical attitudes and behaviors in accordance with applicable norms. Through education, humans can mature themselves in order to be able to distinguish between what is good and what is not good [2].

Education is a substantive thing for human life. Humans really need education in their lives [3]. In essence, education is a conscious effort from a society and government to ensure the survival and life of generations [4]. So that the state is responsible for preparing young generations who have a high national insight and also have a spirit of nationalism in the life of the nation and state [5]. Therefore, it is necessary to improve the understanding of national insight to continue to foster the spirit of nationalism in all elements of the Indonesian nation.
Schools as one of the institutions that help the government in preparing the nation's next generation are responsible for handling educational problems through efforts to guide, educate and train the soul, so that these students have good personalities, have noble character, are creative, independent and become responsible humans 6]. The role of schools is very important in character building efforts. In this context, character education is a school effort carried out jointly by teachers, school leaders and school members through school activities to shape the character, character or personality of students through various virtues contained in religious teachings [7].

The influence of the globalization era is very vulnerable to a decrease in the sense of nationalism [8]. The sense of nationalism among students in Indonesia is getting low. This can be seen when many citizens are prouder of the culture of other nations and are indifferent to the wealth that characterizes their own nation. The way most Indonesian teenagers dress up like celebrities tend to dress up to Western culture. Not many teenagers want to preserve the nation's culture by wearing modest clothes according to the national personality [9]. Judging from 
the attitude, many young people whose behavior are not polite and tend not to have a sense of care for the environment. In addition, brawls between students also often occur. Based on the various facts that exist today, it is very vulnerable to the disintegration of the nation which can destroy the country, so there needs to be a strengthening of the values of nationalism in order to strengthen and unite the Indonesian nation.

Irfani [10] points to the fact that over time, the sense of nationalism is fading. The younger generation is no longer familiar with the national identity. The current younger generation is a generation "confused" with personal problems. This is evidenced by various attitudes in interpreting various important things for the Indonesian State. Simple examples that illustrate how little sense of nationalism, including the Indonesian people today are: 1) At the time of the flag ceremony, there are still many people who do not understand the meaning of the ceremony. The ceremony is a place to honor and appreciate the heroes who have fought hard to take independence from the hands of the invaders. The youth seemed to be busy with their own thoughts, without following the ceremony solemnly.

Nationalism is defined as a political attitude or understanding of the people of a nation which has harmony between culture and territory [11]. They also have the same ideals and goals so that they feel the desire to defend their country, both internally and externally [12]. The indicators of this attitude of nationalism can be seen from: (a) being proud of being an Indonesian nation, (b) loving the country and nation, (c) being willing to sacrifice for the sake of the nation, (d) accepting diversity, (e) being proud of a diverse culture, (f) appreciating the services of heroes, and $(\mathrm{g})$ prioritizing the public interest [13].

This indicator indicates that nationalism is one of the ideologies to remind the younger generation of the persistence of the Indonesian fighters' efforts to win independence. The merits of heroes must be remembered, but being remembered is not enough. The nation's heroes who have died will certainly be proud if their struggle is continued by the current generation because their struggle has not been completed [14]. Politically, the meaning of nationalism is a manifestation of national consciousness that contains aspirations and impetus for a nation, both to seize independence or to get rid of colonialism as well as as an impetus to develop itself and the environment of society, nation and state [15].

Education that is a solution to the problem of fading a sense of nationalism can be optimized with extracurricular activities which are an effective way to help students build feelings of respect as members of the school community [16]. Extracurricular activities that are carried out outside school hours are listed in the program structure according to school conditions and needs [17]. One of the extracurricular activities that is able to shape the character of students through Kedirgantaraan program activities.
The Kedirgantaraan extracurricular activity at the Angkasa Husein Sastranegara Senior High School of Bandung City is used as an effort to foster a sense of nationalism among students. The meaning of the activity itself is any action or movement that is arranged and arranged in an orderly and disciplined manner with the aim of guiding students in exploring the potential of each student.

Kedirgantaraan extracurricular activities are fun because these activities are outside the classroom so that students will find it easier to understand the material in the extracurricular more quickly because students can get real learning, in these activities can form an attitude of independence, discipline, and so on. Kedirgantaraan extracurricular activities are one of the extracurricular activities that can develop children's talents and interests as well as character. Because in these activities there are various kinds of activities that can develop children's character such as love for the country, love for domestic products, upholding the ideology of Pancasila as the basis of the Indonesian state, being proud of Indonesia's potential resources, communicative or friendly, disciplined, honest, independent, responsible, hardworking, social and others. This Kedirgantaraan program is an extracurricular activity at the Angkasa Husein Sastranegara Senior High School of Bandung City, which is a scouting and practicing activity for making miniature airplanes.

With the existence of Kedirgantaraan extracurricular activities at the Angkasa Husein Sastranegara Senior High School of Bandung City, it is hoped that it will not interfere with student achievement in class. On the contrary, it can actually increase student learning achievement, Kedirgantaraan extracurricular activities foster character in fostering a sense of nationalism which is very useful for students' personalities.

\section{THEORETICAL REVIEW}

\subsection{Sense of Nationalism}

In the context of Indonesian history, nationalism is closely related to the spirit of revolution. The Indonesian Revolution has been carried out and has received great reactions in all corners of the archipelago. One of the broader symbols of revolution which contains equality and brotherhood is the way of calling "Bung" which was introduced by Soekarno which immediately became popular throughout Indonesia. The ideas it embodies may at best be regarded as synthesis and "revolutionary brother", "Indonesian nationalist brother" and "republican brother". This revolutionary symbol became the trigger for social revolution movements in various regions [18].

According to Soekarno [19] nationalism which essentially has the desire to live as one group and one nation. This is not to expect and require that the nationalists change to be more Islamic or lean towards 
Marxist, nor do they turn those who are Marxist and have an Islamic ideology turn to nationalists, but actually what we want to achieve is harmony and unity of the three groups.

Soekarno believed in the adage "rukun membikin sentausa" that in fact there are many paths to the direction of unity, it's just how strong it is to fight all differences and the amount of reluctance from all parties involved in the movement. Indonesians must distinguish between the outer aspects of their revolution, namely nationalism, and the social aspects that are part of it. There is a great danger that in concentrating the nationalistic, democratic-based aspects of the revolution, the internal social aspects will be forgotten. By seeing the feudal legacy that continues to live on strongly, the absorption of nationalistic aspects to eliminate aspects of internal democracy will lead to fascism, namely feudalism and super nationalism. What must be emphasized and become the main goal of the Indonesian revolution is not nationalism, but democracy [20].

Mustari [21] states, the meaning of nationalism comes from a word called nation, which is a group of people who have the same language, customs, origin, culture, same fate and responsibility, and their place of residence (country) is the same. According to Hans Kohn [22] nationalism is a notion which argues that the highest loyalty of an individual must be submitted to the national state. This understanding began to emerge when a nation had the same ideals to build a country.

\subsection{Factors Affecting Nationalism}

Mustari [23] stated that the factors of student character becoming nationalists include:

1. Appreciate the services of national figures / heroes

Appreciating the services of national figures / heroes is something that should be instilled in the younger generation [24]. The easiest example is not to let them be or live in a street called a hero, but don't know who he is.

2. Willing to use domestic products

Being willing to use our own products must be instilled in all of us, because by that means we respect our own work and this will be even more proud.

3. Appreciate the natural beauty and culture of Indonesia

Appreciating the natural beauty and culture of Indonesia must also be nurtured in our children, because indeed the Indonesian people have beautiful nature and culture. So great is our culture, that many types of our culture are patented by other countries. For that we need to patent all the peculiarities of our nature and culture to the world. However, this effort requires a high spirit of nationalism.

\section{Memorize the national anthem}

National songs are a must for our children to teach and memorize. Because with these songs they will be carried back to the realm of their parents' struggles in liberating this country, maintaining the independence of this country, and also in fighting to build this country.

5. Choosing to travel within the country

Choosing to travel within the country is a commendable attitude to grow and perpetuate our sense of nationalism. We must know more than foreigners about our own country. Foreigners flock to our country to tour, while we are prouder to go abroad. What is important is that we first recognize our country. Only then can many things be used from this country for ourselves and the Indonesian people in general.

\subsection{Kedirgantaraan Program}

Kedirgantaraan is a discipline that studies everything related to human exploration efforts in the atmosphere or in outer space [25]. Examples are aerodynamics, structure, aircraft design, materials engineering, human and machine interactions, flight control engineering, aeroelasticity, propulsion engineering, and others. Insights in Kedirgantaraan are very important to be given to the younger generation, to instill their sense of nationalism and nationalism.

It is important that Kedirgantaraan insight is given so that the younger generation understands how important this country's sovereignty is in the air to be defended from foreign parties [26]. By fostering love for Kedirgantaraan, a high sense of nationalism and nationalism will be embedded in the souls of the younger generation. The importance of Kedirgantaraan programs in schools, because it has an impact on the soft skills of students. Soft skills are a type of skill that is more related to the sensitivity of a person's feelings towards the environment around them. Because soft skills are related to psychological skills, the resulting impact is more abstract but can still be felt, such as polite behavior, discipline, determination, the ability to cooperate, help others, and so on [27]. Wibowo and Hamrin [28] explained that soft skills are abilities beyond technical and academic abilities, which prioritize intrapersonal and interpersonal skills. In the world of education, soft skills have a very important role, not only for students but also for educators.

There are many opinions of experts and various studies that reveal the importance of the role of soft skills. For example, as revealed in a study conducted at Harvard University in the United States, it is known that a person's success is not determined solely by knowledge (IQ) and technical abilities (hard skills), but is largely determined by the ability to manage oneself and interact with other people (soft skills). In summary, this study reveals that a person's success is determined by the soft skills aspect by 
$80 \%$ and the hard skills aspect only contributes around $20 \%$ [29].

The results of the same study were also conducted by emotional intelligence (EQ) expert Daniel Goleman. From the results of his research, he concluded that success was determined as much as $80 \%$ by soft skills and $20 \%$ by hard skills. Therefore, the impact of soft skills cannot be considered its existence. Soft skills must continue to be honed and strengthened, especially in the midst of increasingly competitive competition [30]. The importance of soft skills has been widely recognized by successful people in the world. In other words, people who are successful in the world can succeed because many are supported by soft skills rather than hard skills.

\section{METHODS}

In this study, researchers used a qualitative approach, because the aim of the researchers themselves wanted to know a description of the development of national insight through Kedirgantaraan programs in fostering a sense of nationalism in students. To make it easier to analyze the data obtained through research, a research method is needed. The method used to analyze the problems in this study is to use the case study research method. According to Creswell, a case study is a research strategy in which the researcher investigates carefully a program, event, activity, process, or group of individuals [31].

The subject under study is determined directly by the researcher. As for the subjects in this study are the Deputy Principal of the Curriculum Sector, the Teacher of the Kedirgantaraan Program, and also the students of the Angkasa Husein Sastranegara High School of Bandung City. While the research location is at Angkasa Husein Sastranegara High School, Bandung, which is located at Jl. LMU Subagio No. 22 Ex. Husein Sastranegara, Cicendo District, Bandung City, West Java 40174.

Data collection techniques or methods used include observation, interviews, and documentation studies. These various data collection techniques can make it easier for researchers to collect various data in the field. Techniques for analyzing or processing data in qualitative research go through the process of compiling, categorizing data, looking for linkages to the contents of various data obtained with the intention of getting their meaning. Data collected and obtained from respondents through interviews, observations, field documentation studies are then described in the form of reports.

\section{RESULT AND DISCUSSION}

\subsection{Form and Model of Kedirgantaraan Program Implementation}

Based on the research results, it can be seen that various forms of habituation carried out by the Angkasa Husein Sastranegara High School of Bandung City to foster a sense of nationalism in students, namely understanding the unity of Indonesia, understanding Pancasila, and learning the importance of national unity.

The form of activities to understand Pancasila, where students are accustomed to reading Pancasila texts every day with the aim that students are embedded in the spirit of Pancasila so that sooner or later the students' sense of nationalism will grow. In accordance with Bakry's opinion [32] that Indonesian nationalism is Pancasila nationalism, which is a form of nationalism with a special characteristic of being devoted to the One and Only, fair and civilized humanity, led by wisdom wisdom in representative deliberations and social justice for all Indonesian people. Thus, it will create national unity, namely the unity of the Indonesian nation.

Based on the above activities, one of the methods or methods used to instill the value of nationalism in students is habituation. Helmawati [33] explained that habituation is a condition in which a person applies behaviors that have never been or are rarely carried out which are often carried out until they eventually become habits.

In line with this opinion, Mulyasa [34] explained that habituation is something that is deliberately done repeatedly so that something can become a habit and something that is practiced. Based on the results of the research, the value of nationalism instilled through habituation activities that have been carried out is love for the environment. , the alma mater and the State of Indonesia, cooperation, respect, respect, tolerance, willingness to sacrifice, responsibility, courtesy and harmony.

The manifestation of a sense of nationalism according to Suparlan Al Hakim, et al. [35] namely fostering harmony, harmony and balance, loving one another, fostering one another, and giving each other, not highlighting differences, but looking for commonalities, increasing love for the environment, working with fellow citizens, the environment , and the government, knowing contradictions and fights, promote unity and integrity through various activities.

Based on the results of the above research, it is known that the Kedirgantaraan program is an activity that studies the insight of the archipelago to create a sense of nationalism in students, so that there is a sense of love for the unitary territory of the Republic of Indonesia.

This is in line with the opinion, according to Muchlas and Hariyanto [36] the values of nationalism include honesty, responsibility, smart, healthy and clean, caring, creative, and mutual cooperation. Cultivating a sense of nationalism is carried out by providing exemplary and advice to students. Providing exemplary and advice is done so that students can behave and have a noble character in accordance with applicable rules.

Helmawati [37] explained that modeling is the most influential method for students. Children see, listen to, and socialize for the first time with their parents, this means that the words and actions of the parents will be in 
the example of their children. The personal teacher has a very big share of the success of education, especially in character education which has a very personal role for students. This is understandable because it is a creature who likes to imitate, including students imitating the teacher's personal in shaping their personality.

Based on the results of the research above, it is known that teachers have a very big role in the Kedirgantaraan program as an effort to foster a sense of nationalism. Kedirgantaraan activities can increase students' sense of nationalism, because they teach the importance of protecting the territory and fellow Indonesian citizens.

These activities are carried out routinely by the school, theoretically routine activities are activities carried out by students continuously and consistently at all times. In line with the above opinion, Mulyasa [38] defines routine activities, namely scheduled habituation, such as (flag ceremony, congregational prayer, regularity, maintenance, hygiene, and personal health). Based on the research results above, it is known that the school has carried out nationalism education through routine activities. The routine activities carried out are the establishment of an Kedirgantaraan program.

The values of nationalism instilled in students in Kedirgantaraan activities are responsibility, discipline, order, togetherness, respect and appreciation for the services of heroes, using domestic products, having a sense of love for the Indonesian state, and love for Indonesian culture. A good citizen, namely someone who can show pride and love for the country, which can be seen from the indication that someone is a nationalist is appreciating the services of national figures / heroes, willing to use domestic products, appreciating the beauty of nature and Indonesian culture, memorizing the national anthem. , choosing to travel within the country, and others.

Based on the explanation above, it can be concluded that the Angkasa Husein Sastranegara High School of Bandung City has made efforts to educate nationalism through routine activities, namely routine Kedirgantaraan program activities.

\subsection{Results of the Implementation of the Kedirgantaraan Program}

The result of Kedirgantaraan program activities is a change in knowledge, attitudes and behavior of a person regarding the life of the nation and state. So that a peaceful life is created, both in the school environment and in community life. Kedirgantaraan activities carried out by Angkasa High School Husein Sastranegara of Bandung City show mixed results. Researchers grouped two aspects, namely understanding and action. The understanding of the meaning of Pancasila and the 1945 Constitution looks very high and enthusiastic in the learning process, this is based on students' interest in international activities carried out by the instructor.
In the action aspect, it shows the same thing, the participation of students in joining the Kedirgantaraan program is very enthusiastic. This indicates that Angkasa Husein Sastranegara High School of Bandung City have an interest, as well as in the realm of action of the students of the Angkasa Husein Sastranegara High School of Bandung City are able to implement the values of nationalism.

Overall, the results of the Kedirgantaraan program activities carried out by the Angkasa Husein Sastranegara High School of Bandung City were successful with indicators of creating a sense of nationalism in the school environment and the existence of achievements obtained by students.

The Kedirgantaraan program carried out by the Angkasa Husein Sastranegara High School of Bandung City is good enough to prevent the fading of the sense of nationalism in students. In addition, the school has optimized the sense of nationalism that grows in students by inviting students to participate in various competitions at the national level.

The results of Kedirgantaraan activities carried out by the Angkasa Husein Sastranegara High School of Bandung City regarding the elements that can prevent radicalism from entering the school environment. The results obtained from Kedirgantaraan program activities are not only at the cognitive level, but also at the affective and psychomotor level. These three aspects are very important for the development of superior Indonesian human resources [39].

In daily routine activities, the Kedirgantaraan program shows changes in students to maintain appreciation and respect between students even though they are of different ethnicities, races and groups, besides that, with the existence of learning methods to understand Indonesia's marine areas, it is able to foster a sense of nationalism in students to maintain the integrity of Indonesian territory. [40].

In other aspects regarding the Kedirgantaraan program carried out by the Angkasa Husein Sastranegara High School of Bandung City as a whole gave significant changes in both the cognitive, affective and psychomotor domains, these good results are due to the material being studied by students is carried out continuously and continuously. This results in students being able to understand the state and marine aspects well. And the activities carried out by the instructor are strengthened through the control of the teacher in every activity carried out by students.

Based on these conditions, the results of the Kedirgantaraan program are able to develop a sense of nationalism in students as a whole. The growth of a sense of nationalism is not only from an affective perspective, but also from a cognitive and psycho-motor perspective. 


\section{CONCLUSION}

The Kedirgantaraan program is able to be a solution to the problem of the fading sense of nationalism in the younger generation. Comprehensive understanding both from a theoretical and practical point of view is able to provide awareness for students of the importance of understanding and protecting Indonesian territory. The Kedirgantaraan program method which is carried out routinely is also able to provide positive results in the form of strengthening a sense of nationalism in the cognitive, affective and psychomotor aspects of students.

\section{REFERENCES}

[1] M. Jagers, J. Robert, D. Rivas-Drake, and B. Williams. "Transformative social and emotional learning (SEL): Toward SEL in service of educational equity and excellence." Educational Psychologist 54, no. 3 (2019): 162-184.

[2] C. Hodges, S. Moore, B. Lockee, T. Trust, and A. Bond. "The difference between emergency remote teaching and online learning." Educause review 27 (2020): 1-12.

[3] R. Kohli. "Lessons for teacher education: The role of critical professional development in teacher of color retention." Journal of Teacher Education 70, no. 1 (2019): 39-50.

[4] Y.K Dwivedi, D.L. Hughes, C. Coombs, I. Constantiou, Y. Duan, J.S. Edwards, B. Gupta et al. "Impact of COVID-19 pandemic on information management research and practice: Transforming education, work and life." International Journal of Information Management 55 (2020): 102211.

[5] H.R. Wicker, "Introduction: theorizing ethnicity and nationalism." In Rethinking Nationalism and Ethnicity, pp. 1-42. Routledge, 2020.

[6] N.A.M. Nasir, N.M. Nor, N.H. Yaacob, and R.A. Rashid. "A Review of Racial Microaggression in Malaysian Educational System and Its Higher Education Institutions." International Journal of Higher Education 10, no. 2 (2021): 151-163.

[7] C. Koch, "Teaching patriotism: Private virtue for the public good in the early republic." In Bonds of Affection, pp. 19-52. Princeton University Press, 2021.

[8] J. Hoberman, "Sportive nationalism and globalization." In Post-Olympism?, pp. 177-188. Routledge, 2020.

[9] A.M. Albantani and A. Madkur. "Think globally, act locally: the strategy of incorporating local wisdom in foreign language teaching in indonesia." International Journal of Applied Linguistics and English Literature 7, no. 2 (2018): 1-8.
[10] A. Irfani, Nasionalisme Bangsa dan Melunturnya Semangat Bela Negara. Jurnal Dakwah: Al-Hikmah, 10(2), 2016, 135-145.

[11] P. Żuk, "Nation, national remembrance, and education-Polish schools as factories of nationalism and prejudice." Nationalities Papers 46, no. 6 (2018): 1046-1062.

[12] A. Smith, Nations and nationalism in a global era. John Wiley \& Sons, 2013.

[13] I.K. Suwandi dan I.P. Sari, I.P, Analisis Karakter Nasionalisme pada Buku Teks Kurikulum 2013 Edisi Revisi 2016 Kelas I SD. Elementary School: Jurnal Pendidikan dan Pembelajaran ke-SD-an, 4(2), 2017, 151-161.

[14] I. Tyler, "Resituating Erving Goffman: From stigma power to black power." The Sociological Review 66, no. 4 (2018): 744-765.

[15] R. Sazzad, "Language movements in Sri Lanka and Pakistan: exploring global conflicts of language and cultural rights with other human rights." The International Journal of Human Rights (2020): 1-17.

[16] T. Lickona, Educating For Character, How Our Schools Can Teach Respect And Responsibility, Bantam Books, New York, 1993.

[17] I. Steinmann, R. Strietholt, and D. Caro. "Participation in extracurricular activities and student achievement: Evidence from German all-day schools." School Effectiveness and School Improvement 30, no. 2 (2019): 155-176.

[18] G.M.T. Kahin, Nationalism and Revolutions in Indonesia. Ab. Nin Bakdi Soemanto. Refleksi Pergumulan Lahirnya Republik; Nasionalisme dan Revolusi di Indonesia. Surakarta: UNS Press \& Pustaka Sinar Harapan, 1995.

[19] Soekarno, Di bawah bendera revolusi, jilid I. (Cetakan Ketiga). Jakarta: Panitia Penerbit Di Bawah Bendera Revolusi, 1964.

[20] Op.Cit, Kahin (1995).

[21] M. Mustari, Nilai Karakter. Yogyakarta: LaksBang PRESSindo, 2011.

[22] H. Kohn, Nasionalisme: Arti dan Sejarahnya (Jakarta : Penerbit Erlangga), 1985.

[23] Op,Cit, Mustari (2011).

[24] U. Khodjamkulov, K. Makhmudov, and A. Shofkorov. "The Issue of Spiritual and Patriotic Education of Young Generation in the Scientific, Political and Literary Heritage of Central Asian Thinkers." International Journal of Psychosocial Rehabilitation 24, no. 05 (2020): 6694-6701.

[25] L. Zuccarelli, L. Galasso, R.Turner, E.J.B. Coffey, L. Bessone, and G. Strapazzon. "Human physiology during exposure to the cave environment: A 
systematic review with implications for Kedirgantaraan medicine." Frontiers in physiology 10 (2019): 442.

[26] M. Oguro, Ensuring Japan's Future Air Security: Recommendations for Enhancing the JASDF's Readiness to Confront Emerging Threats. Brookings, 2018.

[27] M.A Rokhimawan, Pengembangan Soft Skill Guru dalam Pembelajaran Sains SD/MI Masa Depan yang Bervisi Karakter Bangsa, Jurnal Al-Bidayah, 4(1), 2012.

[28] A. Wibowo dan Hamrin, Menjadi Guru Berkarakter (Strategi Membangun Kompetensi dan Karakter Guru). Yogyakarta: Pustaka Pelajar, 2012.

[29] Ibid.

[30] I. Apandi, Guru Kalbu Penguatan Soft Skill untuk Mewujudkan Guru Profesional dan Berkarakter. Bandung: CV. Smile's Indonesia Institute, 2015.

[31] J.W. Creswell, Research Design Pendekatan Kualitatif, Pendekatan Kuantitatif, dan Mixed. Yogyakarta: Pustaka Pelajar, 2013.

[32] N.M. Bakry, Pendidikan Kewarganegaraan, Yogyakarta: Pustaka Pelajar, 2012.
[33] Helmawati, pendidikan karakter sehari-hari, Bandung: PT. Remaja Rosdakarya, 2017.

[34] Mulyasa, manajemen pendidikan karakter. Jakarta: PT. Bumi Aksara, 2014.

[35] S. Al Hakim, dkk, Pendidikan Kewarganegaraan Dalam Konteks Indonesia. Malang: Madani Kelompok Intrans Publishing Wisma Kalimetro, 2016.

[36] Hariyanto dan M. Samani, konsep dan model pendidikan karakter, Bandung: PT. Remaja Rosdakarya, 2013.

[37] Op,Cit, Helmawati (2017).

[38] Op,Cit, Mulyasa (2014).

[39] E.H. Tyas, S. Sunarto, and L. Naibaho. "Building Superior Human Resources through Character Education." TEST Engineering \& Management 83 (2020): 11864-11873.

[40] A. Dirwan, "Improving Nationalism through Civic Education among Indonesian Students." OIDA International Journal of Sustainable Development 11, no. 03 (2018): 43-58. 